\title{
Nitrogen utilization, preweaning nutrient digestibility, and growth effects of Holstein dairy calves fed 2 amounts of a moderately high protein or conventional milk replacer
}

\author{
C. E. Chapman,${ }^{* 1}$ T. M. Hill, $†$ D. R. Elder, $\ddagger$ and P. S. Erickson ${ }^{\star 2}$ \\ *Department of Biological Sciences, University of New Hampshire, Durham 03824 \\ †Provimi North America, Brookville, $\mathrm{OH} 45309$ \\ $\ddagger$ Animal Resource Office, University of New Hampshire, Durham 03824
}

\begin{abstract}
Studies have shown that calves fed milk replacers (MR) with crude protein (CP) concentrations greater than $20 \%$, as typically found in conventional MR, have higher dry matter intakes (DMI) and greater average daily gains (ADG) but consume less starter, which can lead to stress during weaning and reduced rumen development. The greater amount of $\mathrm{CP}$ being fed to preweaned calves may alter their nitrogen $(\mathrm{N})$ balance, and excess $\mathrm{N}$ may be excreted in the urine. The objective of this study was to determine $\mathrm{N}$ utilization in preweaned calves fed diets varying in the amount of $\mathrm{CP}$ and MR fed. This study used 24 newborn dairy heifer calves blocked by birth and randomly assigned to 1 of 3 treatments: (1) $446 \mathrm{~g}$ dry matter (DM) of a conventional MR (CON; 20\% CP, 20\% fat), (2) 669 g DM of a moderately high protein MR (moderate; MOD; 26\% CP, $18 \%$ fat), or (3) $892 \mathrm{~g} \mathrm{DM}$ of a moderately high protein MR (aggressive; AGG; 26\% CP, 18\% fat). All calves had ad libitum access to starter and water. Both MR and starter were medicated with decoquinate. During weaning (d 43-49), the morning MR feeding ceased. On d 50, all MR feedings ended; however, starter and water intakes were continuously recorded until d 56. At $5 \mathrm{wk}$ of age, urine was collected using urinary catheters for $3 \mathrm{~d}$ and chromium oxide was administered by bolus at $2 \mathrm{~g} / \mathrm{d}$ for $7 \mathrm{~d}$ to estimate $\mathrm{N}$ efficiency. Calves fed MOD and AGG had similar starter intakes, feed efficiencies, and ADG, with the combined treatments having reduced starter intakes (258 vs. $537 \mathrm{~g} / \mathrm{d}$ ), greater ADG (674 vs. $422 \mathrm{~g} / \mathrm{d})$, and improved feed efficiency ( 0.57 vs. 0.45 gain:feed) compared with CON calves preweaning. However, DMI and water intake were similar across all treatments. Results from the $\mathrm{N}$ utilization phase

\footnotetext{
Received August 18, 2016.

Accepted October 4, 2016.

${ }^{1}$ Current address: Penn State Extension-Bradford County, Towanda,

${ }^{2}$ Corresponding author: peter.erickson@unh.edu
} PA 18848.
\end{abstract}

showed that MOD and AGG treatments had similar but lower $\mathrm{N}$ efficiency compared with CON calves (45.5 vs. 52.7\%). This could be due to MOD- and AGG-fed calves having greater urine volume and thereby, greater combined urine $\mathrm{N}$ output compared with CON calves $(17.6$ vs. $12.1 \mathrm{~g} / \mathrm{d})$. In summary, feeding $>0.66 \mathrm{~kg}(\mathrm{DM})$ from a $26 \%$ CP MR increased ADG and improved feed efficiency during the preweaning period but reduced starter intake and lowered $\mathrm{N}$ efficiency.

Key words: dairy calf, high protein milk replacer, nitrogen efficiency, digestibility

\section{INTRODUCTION}

Conventional calf feeding programs have restricted the amount of milk and milk replacer (MR) fed during the preweaning period in an effort to encourage more solid feed intake, minimize the cost of feeding and labor, and reduce the potential for scours and other diseases (Kertz et al., 1979; Otterby and Linn, 1981; Davis and Drackley, 1998). The standard recommendations have been to feed whole milk at 8 to $10 \%$ of calf BW or 454 to $567 \mathrm{~g}$ of MR powder regardless of body size twice a day until weaning to provide enough energy to support minimal BW gains of 0.3 to $0.4 \mathrm{~kg} / \mathrm{d}$, depending upon starter intake, management, health, and environmental changes to meet requirements for maintenance under thermoneutral conditions (Davis and Drackley, 1998). Greater starter intakes before weaning ensure that weight gains and intakes will be sustained after weaning (Kertz et al., 1979). These recommendations are in contrast to numerous studies that have demonstrated calves fed greater intakes of milk solids as well as greater protein concentrations in MR have greater DMI, ADG, and overall skeletal measurements, (Appleby et al., 2001; Jasper and Weary, 2002) but calves consume less starter, which can lead to a more stressful time during weaning and less rumen development (Huber et al., 1984; Cowles et al., 2006; Hill et al., 2010; Guindon et al., 2015), which places this type of program in 
direct opposition to the conventional calf management described above. Currently, an intensified optimum MR with CP levels greater than the $20 \%$ found in conventional MR is being fed to calves, which more closely resembles whole milk (Diaz et al., 2001). Feeding a MR with $>25 \% \mathrm{CP}$ at an rate increasing with age up to 900 to $1,200 \mathrm{~g}$ of $\mathrm{DM} / \mathrm{d}$ has allowed for greater BW gain than conventional MR programs (Diaz et al., 2001; Tikofsky et al., 2001; Blome et al., 2003; Bartlett et al., 2006). These high feeding rates can capitalize on the rapid and efficient early lean growth potential of calves and allow for increased body protein deposition and growth rate (Kertz and Loften, 2013).

The decrease in starter intake during the preweaning period with these high feeding rates of milk and MR can inhibit rumen development and digestibility of nutrients postweaning (Terré et al., 2007a,b; Hill et al., 2010; Chapman et al., 2016). Chapman et al. (2016) showed that calves fed $0.87 \mathrm{~kg}$ of DM of a $27 \% \mathrm{CP}$, $17 \%$ fat MR preweaning had a reduction in postweaning OM digestibility of $11 \%$ and a reduction in NDF digestibility of $28 \%$ compared with control calves fed $0.44 \mathrm{~kg}$ of DM of a $21 \% \mathrm{CP}, 21 \%$ fat MR. Terré et al. (2007a,b) also showed that digestibility of NDF was $40 \%$ less in calves fed greater levels of MR. Results from these studies show that large amounts of MR fed preweaning may further impair fiber digestion as the calf ages. Excessive feeding of CP to lactating cows and growing replacement heifers has been shown to increase fecal and urinary $\mathrm{N}$, which can cause environmental problems (Wilkerson et al., 1997). These high feeding rates of milk and MR may also have an effect on $\mathrm{N}$ utilization and preweaning nutrient digestion in the calf. The objective of this experiment was to determine $\mathrm{N}$ utilization, preweaning nutrient digestibility, and growth effects in calves fed diets varying in the amount of protein and the amount of MR fed. The hypothesis was that calves fed a conventional control MR will consume more starter throughout the preweaning period and be more $\mathrm{N}$ efficient compared with calves fed a moderately high protein MR.

\section{MATERIALS AND METHODS}

\section{Calves, Diets, and Treatments}

This experiment was reviewed and approved by the University of New Hampshire Institutional Animal Care and Use Committee (Protocol \#130506). Twentyfour Holstein heifer calves (initial BW of $41.6 \pm 4.8 \mathrm{~kg}$ ) were blocked by birth date and randomly assigned at birth to 1 of 3 treatments in a randomized complete block design. The treatments were (1) $446 \mathrm{~g} \mathrm{DM}$ of a conventional MR (CON; 20\% CP, 20\% fat), (2) 669 g DM of a moderately high protein MR (moderate, MOD; $26 \%$ CP, $18 \%$ fat), or (3) 892 g DM of a moderately high protein MR (aggressive, AGG; $26 \% \mathrm{CP}$, $18 \%$ fat). Both MR products were provided by Provimi North America (Brookville, $\mathrm{OH}$ ) and medicated with decoquinate. The 56-d study was conducted from $\mathrm{Au}-$ gust 2013 to March 2014.

Calves were removed from their dams immediately after birth and transferred to an individual calf pen (1 $\times 2.15 \mathrm{~m}$ ) in a naturally ventilated enclosed calf room, and navels were dipped in $7 \%$ iodine. Pens had a mattress topped with kiln-dried sawdust. Calves were fed 2 L of good quality colostrum $(>50 \mathrm{~g} / \mathrm{L}$ of $\mathrm{IgG})$ at birth and $2 \mathrm{~L} 12 \mathrm{~h}$ later with a nipple bottle. All calves were vaccinated for Escherichia coli (Bar-Guard 99, Boehringer Ingelheim, Ingelheim, Germany) and rotavirus/ coronavirus (Calf Guard, Pfizer Animal Health, Exton, PA) in accordance with university protocol.

Calves were fed a $20.7 \%$ CP textured starter on a DM basis (Table 1; Provimi North America) and water ad libitum starting at $2 \mathrm{~d}$ of age and continuing for the entire 56-d trial. Initial BW and skeletal measurements were taken before calves started the MR treatment. Starter orts were collected and replaced daily at 0800 h. The starter comprised whole corn and oats, molasses, and a protein pellet. The amount of starter offered each day was regulated by the previous day's intake. When refusals weighed $<227 \mathrm{~g}$, the next feeding was raised by $227 \mathrm{~g}$ to ensure constant access to starter. Fresh water was replaced twice daily at 0800 and 1700 h. Water refusals and fresh water offered were weighed and recorded at each feeding.

Calves on CON were fed $227 \mathrm{~g}$ of 20:20 (CP:fat) MR reconstituted to $10.7 \%$ solids $(0800$ and $1700 \mathrm{~h})$ from $\mathrm{d}$ 2 to 42 (1.89 L twice daily). Calves on MOD were fed $340 \mathrm{~g}$ of $26: 18$ (CP:fat) MR reconstituted to $13 \%$ solids (0800 and $1700 \mathrm{~h})$ from d 2 to $42(2.27 \mathrm{~L}$ twice daily). Calves on AGG were fed $340 \mathrm{~g}$ of $26: 18$ (CP:fat) MR reconstituted to $13 \%$ solids (0800 and $1700 \mathrm{~h}$ ) from d 2 to 6 (2.27 L twice daily) and then $454 \mathrm{~g}$ of $26: 18$ (CP:fat) MR reconstituted to $13 \%$ solids (0800 and

Table 1. Nutrient composition of milk replacers (MR) and calf starter (DM basis)

\begin{tabular}{lccc}
\hline Item & Control MR & $\begin{array}{c}\text { Moderate/ } \\
\text { aggressive MR }\end{array}$ & Starter \\
\hline DM, \% & 98.2 & 98.2 & 90.1 \\
CP, \% & 19.9 & 26.3 & 20.7 \\
Fat, \% & 20.7 & 18.6 & 3.1 \\
ADF, \% & - & - & 7.6 \\
NDF, \% & - & - & 16.0 \\
Starch, \% & - & 5.9 & 38.7 \\
Ash, \% & 5.3 & & 7.5 \\
\hline
\end{tabular}


$1700 \mathrm{~h}$ ) from d 7 to 42 (3.03 L twice daily). On d 43 to 49 , calves on all treatments were fed once daily at 0800 h. Calves were fed MR and water in pails. On d 50, all milk feedings ceased. Calves remained on trial for $7 \mathrm{~d}$ postweaning for a total of $56 \mathrm{~d}$.

\section{Feed Analysis}

Dry matter intake was calculated on a daily basis. Samples were dried in a forced hot-air convection oven at $55^{\circ} \mathrm{C}$ for $48 \mathrm{~h}$ (Binder, Bohemia, NY). The composited samples were then ground through a $1-\mathrm{mm}$ screen using a Wiley mill (Thomas Scientific, Swedesboro, NJ). Samples were sent to Analab (Fulton, IL) for analysis of ADF (method 973.18), NDF (method 2002.04), CP (method 990.03), starch (enzymatic method using glucose Trinder), crude fat (method 920.39), ash (method 942.05), Ca, P, Mg, and $\mathrm{K}$ (method 985.01), and $\mathrm{S}$ (method 923.01) according to AOAC International (1999) methods. In the MR, fat was determined by saponification with $\mathrm{KOH}$ in ethyl alcohol. The fat was liberated from the soaps with $\mathrm{HCl}$ and extracted with petroleum ether (AOAC International, 1995). Chemical analyses of MR and starter are shown in Table 1. Metabolizable energy was calculated by overriding the data in the NRC dairy evaluation program (NRC, 2001) with the values from the analyses for MR and starter. Concentrations of ME for starter, conventional $\mathrm{MR}$, and moderately high protein MR were estimated to be $3.20,4.82$, and $4.80 \mathrm{Mcal} / \mathrm{kg}$, respectively.

\section{Measurements and Blood Sampling}

Calves were weighed and measured for withers height, hip height, hip width, heart girth, and body length once weekly for the duration of the trial. Calves were weighed on a platform scale (VS-2000, A and A Scales LLC, Prospect Park, NJ). Withers and hip heights were measured with a sliding-scale height stick with a bubble level. Heart girth and body lengths were measured using a weight tape, and hip widths were measured using a Hip-O-Meter (Dairy Innovations, Attica, NY). Calves born on Friday through Monday were weighed and measured on the following Monday, and every Monday thereafter at $1100 \mathrm{~h}$. Calves born on Tuesday through Thursday were weighed and measured on the following Thursday and every Thursday thereafter at $1100 \mathrm{~h}$. Blood samples were collected weekly on weigh days at $1100 \mathrm{~h}$ (3 h after feeding) via jugular venipuncture using 10-mL tubes (BD Vacutainer, Becton Dickinson, Franklin Lakes, NJ) without anticoagulant and 22-gauge needles. Blood samples were centrifuged at $1,278 \times g$ at $4^{\circ} \mathrm{C}$ for $20 \mathrm{~min}$ (5430R, Eppendorf,
Hamburg, Germany). Serum was aspirated and stored at $-20^{\circ} \mathrm{C}$ until further analysis for glucose, BHB, and serum urea N. Serum glucose concentrations were measured in duplicate using Wako Autokit for Glucose (Wako Diagnostics, Mountain View, CA). Concentrations were read on a DU 520 spectrophotometer according to manufacturer's instructions (Beckman Coulter Inc., Brea, CA). Serum BHB concentrations were measured in triplicate using the BHB Colorimetric Assay Kit from Cayman Chemical (Ann Arbor, MI) and read using a plate reader (Chromate, Awareness Technology Inc., Palm City, FL) according to the manufacturer's instructions. Urea concentrations were measured in duplicate using the diacetyl-monoxime method and measured colorimetrically using an UV/visible spectrophotometer (Beckman Coulter Inc.) set at a wavelength of $540 \mathrm{~nm}$.

\section{Nitrogen Balance Measurements}

Eighteen calves $(\mathrm{n}=6)$ underwent a nitrogen balance experiment at 36 to $42 \mathrm{~d}$ of age. Urinary catheters were used for total urinary collection for $3 \mathrm{~d}$. Calves were grouped based on age and housed in a ventilated barn designed for ease of total collection. The barn contained 6 individual tiestalls $(0.81 \times 1.83 \mathrm{~m})$ bedded with kiln-dried sawdust with ad libitum access to starter and water. Calves had enough space to lie down, but in order to keep catheters secure, they were unable to turn around. An area behind the calf was allocated for urine collection jugs and they were secured below the calves to allow gravity flow of urine. Urine was collected via transurethral catheterization for $3 \mathrm{~d}$ using 8-, 10-, or 12-Fr Foley catheters (ClearView Silicon Foley Catheter, SurgiVet, Waukesha, WI) depending on the size and weight of the calf at the time of placement. The catheter was connected to flexible plastic tubing and secured with tag cement to the calf's side to prevent removal. The tubing flowed with gravity through a stopper and into a collection jug. Collection jugs were changed and weighed for volume (Pelouze Rubbermaid, Winchester, VA) at $1600 \mathrm{~h}$ throughout the collection period. One hundred milliliters of $6 \mathrm{~N} \mathrm{HCl}$ was added to a jug before urine collection. Two 40-mL aliquots were subsampled at $1600 \mathrm{~h}$ every day of the collection period and stored at $-20^{\circ} \mathrm{C}$ until further analysis of total N. Total N was measured by method 990.03 (AOAC International, 1999) by Analab.

\section{Digestibility Measurements}

Chromium oxide (Sigma-Aldrich Corp., St. Louis, MO) was used as a marker for purposes of estimat- 
ing apparent total-tract nutrient digestibility and $\mathrm{N}$ efficiency. The equation used to estimate digestibility was $100-[100 \times(\%$ chromium in feed $/ \%$ chromium in feces $) \times(\%$ nutrient in feces $/ \%$ nutrient in feeds $)]$. All 24 calves underwent the digestibility phase when they were 36 to $42 \mathrm{~d}$ of age. Chromium oxide was dosed at $2 \mathrm{~g} / \mathrm{d}$ and split into 2 doses to be administered in gelatin capsules. Capsules were given orally twice daily at 0730 and $1930 \mathrm{~h}$ for $7 \mathrm{~d}$. Feed samples were taken on $\mathrm{d} 2$ through 5 , and ort samples were taken on $\mathrm{d} 3$ through 6. Starter and orts were composited over the sampling days. Milk replacer samples were retained. Calves consumed all MR provided, resulting in $0 \mathrm{MR}$ orts. Fecal grab samples were collected for the last $4 \mathrm{~d}$ every $12 \mathrm{~h}$ to represent a $24-\mathrm{h}$ period (d 4: 0600 and $1800 \mathrm{~h}$; d 5: 0900 and $2100 \mathrm{~h}$; d 6: 0 and $1200 \mathrm{~h}$; and d 7: 0300 and $1500 \mathrm{~h}$ ) by stimulating defecation or collected directly from the rectum. Samples were pooled by calf over the $4 \mathrm{~d}$ to obtain a single composite and then frozen at $-20^{\circ} \mathrm{C}$ until further analysis. Composite fecal samples were thawed at room temperature and placed in aluminum trays in a forced-air oven at $55^{\circ} \mathrm{C}$ until completely dried (approximately $72 \mathrm{~h}$ ). Dried starter, MR, orts, and fecal samples were ground to pass through a 1-mm screen Wiley mill (Thomas Scientific) and sent to Analab for analysis of CP, starch, fat, ash, NDF, and ADF, as described previously, and chromium (AOAC International, 1999; method 990.08) concentrations were determined in the feces of calves.

\section{Statistical Analysis}

Weekly DMI, ME intake (MEI), ADG, skeletal measurements, ADG/DMI, ADG/MEI, ADG/CP, intakes of DM, CP, and fat, and blood metabolites were analyzed as a randomized complete block design using repeated measures determined in the MIXED procedure of SAS (version 9.4; SAS Institute Inc., Cary, NC) according to the following model:

$$
Y_{i j k}=\mu+B_{i}+T_{j}+W_{k}+T W_{j k}+E_{i j k},
$$

where $Y_{i j k}=$ dependent variable; $\mu=$ overall mean; $B_{i}$ $=$ random effect of block $i(i=1, \ldots, 8) ; T_{j}=$ effect of MR type or amount of the jth treatment (either conventional or moderately high protein fed at $669 \mathrm{~g} / \mathrm{d}$ or $892 \mathrm{~g} / \mathrm{d}) ; W_{k}=$ effect of the $k$ th week $(k=1, \ldots, 8)$, $T W_{j k}=$ effect of interaction between the $j$ th treatment and the $k$ th week; $E_{i j k}=$ residual error $\sim N\left(0, \sigma_{e}^{2}\right)$, and $\sigma^{2}$ is the population standard deviation.

Intakes, growth, and blood metabolites for the weaning and postweaning week were analyzed as a randomized complete block design using the MIXED procedure of SAS (version 9.4; SAS Institute Inc.) according to the following model:

$$
Y_{i j}=\mu+B_{i}+T_{j}+E_{i j},
$$

where $Y_{i j}=$ dependent variable; $\mu=$ overall mean; $B_{i}=$ random effect of block $i(i=1, \ldots, 8) ; T_{j}=$ effect of MR type or amount of the jth treatment (either conventional or moderately high protein fed at $669 \mathrm{~g} / \mathrm{d}$ or $892 \mathrm{~g} / \mathrm{d}) ; E_{i j}=$ residual error $\sim N\left(0, \sigma_{e}^{2}\right)$, and $\sigma^{2}$ is the population standard deviation.

Digestibility and $\mathrm{N}$ balance measurements were analyzed as a randomized complete block design using the MIXED procedure of SAS (version 9.4; SAS Institute Inc.) according to the following model:

$$
Y_{i j}=\mu+B_{i}+T_{j}+E_{i j},
$$

where $Y_{i j}=$ dependent variable; $\mu=$ overall mean; $B_{i}=$ random effect of block $i(i=1, \ldots, 8) ; T_{j}=$ effect of MR type or amount of the $j$ th treatment (either conventional or moderately high protein fed at $669 \mathrm{~g} / \mathrm{d}$ or $892 \mathrm{~g} / \mathrm{d}) ; E_{i j}=$ residual error $\sim N\left(0, \sigma_{e}^{2}\right)$, and $\sigma^{2}$ is the population standard deviation.

Initial weight, skeletal measurements, and blood metabolites were used as covariates in the experimental design. Week was used as the repeated measure. Data were examined using 4 covariance structures: unstructured, compound symmetry, Toeplitz, and first-order autoregressive. For first-order autoregressive, block was considered random. The covariance structure with the smallest Bayesian information criterion value was selected. Degrees of freedom were calculated using the Kenward-Roger approximation option of the MIXED procedure. Least squares means were determined for each treatment and the Tukey option of SAS was selected to differentiate least squares means among treatments. Significance treatment effects were determined at a probability of $P \leq 0.05$ and trends were defined at $0.05<P \leq 0.10$.

\section{RESULTS}

\section{Preweaning Period}

Data collected during the preweaning period (wk 1 to 6) are shown in Table 2. Initial BW of calves were not different among treatments. Calves on the AGG treatment consumed more MR than CON and MOD calves $(P<0.05)$. Calves fed AGG and MOD had similar starter intakes, and calves on both treatments consumed about 50\% less starter than CON-fed calves. Dry matter intake was similar among treatments; however, AGG calves had similar MEI to MOD calves, and 
greater MEI than CON calves $(P<0.05)$. Water intake was similar among all treatments. Calves fed AGG and MOD had greater efficiency (ADG/DMI) compared with CON-fed calves $(P<0.05)$, but when expressed as ADG/MEI, no differences were noted among treatments. Intakes of fat and $\mathrm{CP}$ were greatest for $\mathrm{AGG}$ calves $(P<0.05)$, but efficiency of ADG per unit of $\mathrm{CP}$ did not differ among treatments. Intakes of DM and $\mathrm{ME}$ per kilogram of BW did not differ among treatments but intakes of fat and $\mathrm{CP}$ per kilogram of BW were greatest for AGG calves $(P<0.05)$. Withers height, hip height, hip width, and heart girth were greater for calves fed AGG than CON $(P<0.05)$. No differences were seen in blood metabolites for glucose or serum urea N; however, calves on CON had greater BHB concentrations than MOD and AGG $(P<0.05)$. We detected significant treatment $\times$ week interactions, including MR intake, starter intake, DMI, MEI, CP, and fat intake, weight, ADG, and efficiency measurements $(P<0.05)$.

\section{Weaning Week}

Intake, growth measurements, and blood metabolites taken during the weaning week are shown in Table 3. Calves fed AGG consumed more MR than MOD- and CON-fed calves $(P<0.05)$; however, no differences were seen among treatments in DMI, starter intake, water intake, MEI, or ADG. Efficiency of ADG per unit of CP and unit of MEI did not differ among treatments. Intake of fat was greatest for AGG and MOD calves $(P<0.05)$ but similar among treatments for intake of CP. Intakes of DM, CP, and ME per kilogram of BW did not differ among treatments but intake of fat per kilogram of BW was greatest for AGG-fed calves $(P<0.05)$. Withers height, hip height, and hip width remained greater for calves fed AGG than for those fed CON. No differences were seen in blood metabolites for glucose or serum urea $\mathrm{N}$; however, calves on CON had greater $\mathrm{BHB}$ concentrations than calves on MOD and AGG $(P<0.05)$.

Table 2. Preweaning intake, growth, and blood measurements of calves fed 3 milk replacer (MR) programs ${ }^{1}$ (d 1 to 42 )

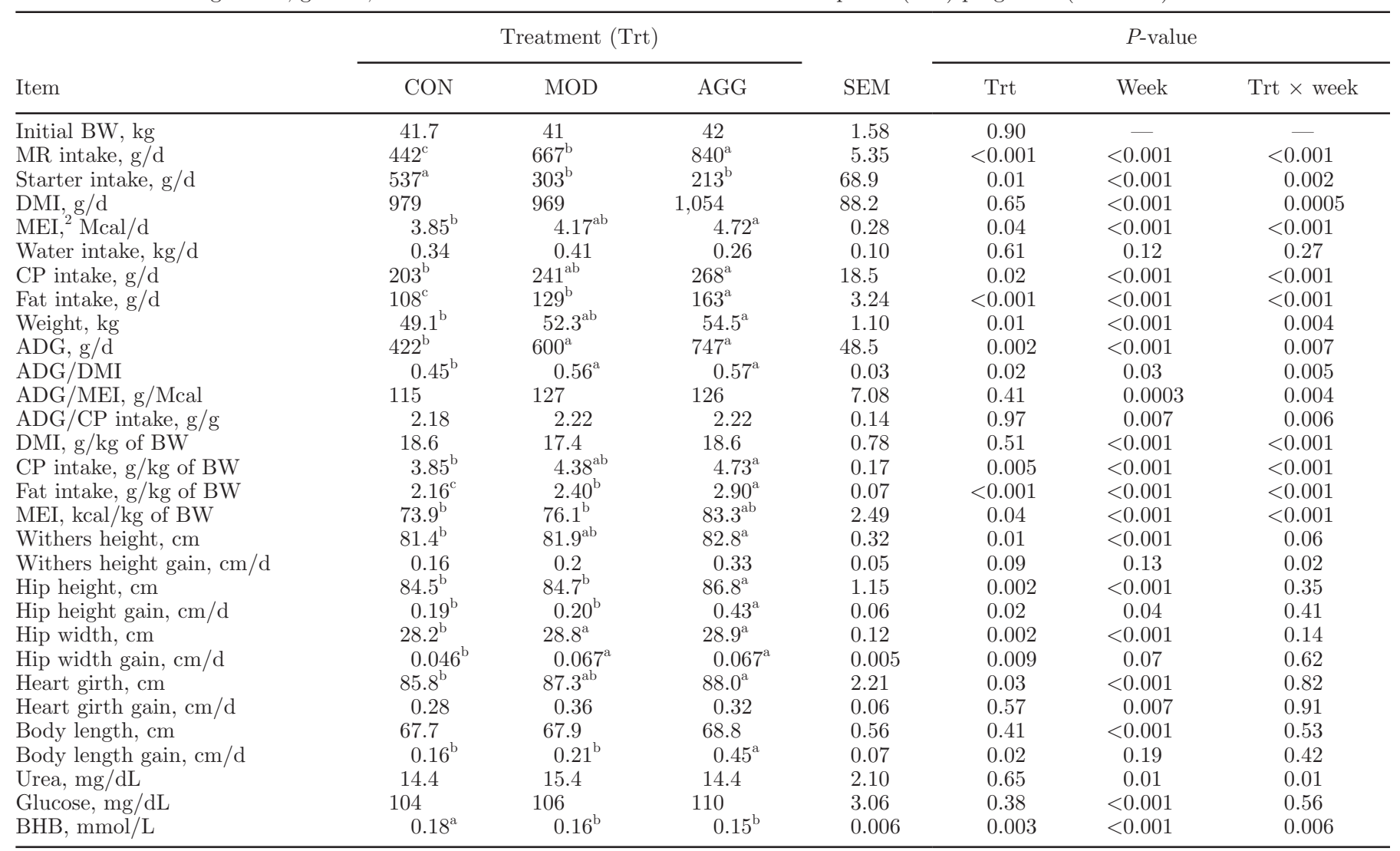

${ }^{\mathrm{a}-\mathrm{c}}$ Means in the same row with different superscripts differ $(P<0.05)$.

${ }^{1}$ Treatment $\mathrm{CON}=446 \mathrm{~g}$ of a $20 \% \mathrm{CP}, 20 \%$ fat MR; MOD $=669 \mathrm{~g}$ of a $26 \% \mathrm{CP}, 18 \%$ fat MR; AGG $=892 \mathrm{~g}$ of a $26 \% \mathrm{CP}, 18 \%$ fat $\mathrm{MR}$.

${ }^{2}$ Estimation of ME intake. 
Table 3. Weaning week intake, growth, and blood measurements of calves fed 3 milk replacer (MR) programs ${ }^{1}$ (d 43 to 49$)$

\begin{tabular}{lccccc}
\hline & \multicolumn{3}{c}{ Treatment (Trt) } & & P-value \\
\cline { 2 - 4 } \cline { 5 - 6 } Item & CON & MOD & AGG & SEM & Trt \\
\hline MR intake, g/d & $223^{\mathrm{c}}$ & $333^{\mathrm{b}}$ & $446^{\mathrm{a}}$ & 1.11 & $<0.001$ \\
Starter intake, g/d & 1,669 & 1,415 & 1,193 & 142 & 0.10 \\
DMI, g/d & 1,892 & 1,748 & 1,639 & 142 & 0.47 \\
MEI, Mcal/d & 6.41 & 6.13 & 5.96 & 0.46 & 0.77 \\
Water intake, kg/d & 1.48 & 1.31 & 0.95 & 0.18 & 0.16 \\
CP intake, g/d & 395 & 385 & 368 & 29.1 & 0.81 \\
Fat intake, g/d & $98.5^{\mathrm{b}}$ & $106.2^{\mathrm{ab}}$ & $120.3^{\mathrm{a}}$ & 4.48 & 0.01 \\
Weight, kg & 69.7 & 73.0 & 74.4 & 2.07 & 0.30 \\
ADG, g/d & 1,007 & 998 & 852 & 125 & 0.63 \\
ADG/DMI & 0.53 & 0.59 & 0.52 & 0.08 & 0.80 \\
ADG/MEI, g/Mcal & 157 & 166 & 143 & 22.0 & 0.77 \\
ADG/CP intake, g/g & 2.56 & 2.65 & 2.31 & 0.35 & 0.78 \\
DMI, g/kg of BW & 26.9 & 23.4 & 22 & 1.44 & 0.08 \\
CP intake, g/kg of BW & 5.63 & 5.18 & 4.95 & 0.29 & 0.27 \\
Fat intake, g/kg of BW & $1.41^{\mathrm{b}}$ & $1.46^{\mathrm{b}}$ & $1.62^{\mathrm{a}}$ & 0.03 & 0.002 \\
MEI, kcal/kg of BW & 91.5 & 82.4 & 80.1 & 4.48 & 0.20 \\
Withers height, cm & $87.1^{\mathrm{b}}$ & $88.2^{\mathrm{ab}}$ & $89.8^{\mathrm{a}}$ & 0.47 & 0.005 \\
Withers height gain, cm/d & 0.24 & 0.30 & 0.28 & 0.05 & 0.63 \\
Hip height, cm & $90.2^{\mathrm{b}}$ & $91.3^{\mathrm{ab}}$ & $93.0^{\mathrm{a}}$ & 0.51 & 0.006 \\
Hip height gain, cm/d & 0.24 & 0.33 & 0.22 & 0.04 & 0.18 \\
Hip width, cm & $30.0^{\mathrm{b}}$ & $30.7^{\mathrm{ab}}$ & $31.0^{\mathrm{a}}$ & 0.26 & 0.04 \\
Hip width gain, cm/d & 0.066 & 0.065 & 0.075 & 0.03 & 0.95 \\
Heart girth, cm & 95.2 & 96.6 & 97.3 & 1.07 & 0.43 \\
Heart girth gain, cm/d & 0.45 & 0.43 & 0.23 & 0.09 & 0.21 \\
Body length, cm & $74.4^{\mathrm{b}}$ & $75.4^{\mathrm{ab}}$ & $77.3^{\mathrm{a}}$ & 0.76 & 0.05 \\
Body length gain, cm/d & 0.2 & 0.36 & 0.4 & 0.07 & 0.12 \\
Urea, mg/dL & 24.1 & 21.1 & 20.2 & 1.60 & 0.23 \\
Glucose, mg/dL & 88.0 & 92.5 & 88.3 & 2.13 & 0.28 \\
BHB, mmol/L & $0.30^{\mathrm{a}}$ & $0.24^{\mathrm{b}}$ & $0.21^{\mathrm{b}}$ & 0.02 & 0.005 \\
\hline
\end{tabular}

${ }^{a-c}$ Means in the same row with different superscripts differ $(P<0.05)$.

${ }^{1}$ Treatment $\mathrm{CON}=446 \mathrm{~g}$ of a $20 \% \mathrm{CP}, 20 \%$ fat $\mathrm{MR} ; \mathrm{MOD}=669 \mathrm{~g}$ of a $26 \% \mathrm{CP}, 18 \%$ fat $\mathrm{MR} ; \mathrm{AGG}=892$ g of a $26 \% \mathrm{CP}, 18 \%$ fat MR.

${ }^{2}$ Estimation of ME intake.

\section{Postweaning Week}

During the postweaning period (Table 4), no differences were noted among treatments in DMI, MEI, water intake, CP intake, fat intake, or ADG. Feed efficiency, expressed as either ADG/DMI or ADG per unit of $\mathrm{CP}$ and unit of MEI, did not differ among treatments. Intakes of DM, CP, fat, and MEI per kilogram of BW did not differ among treatments. No differences were noted in skeletal measurements except that calves fed AGG and MOD had greater hip widths compared with CON-fed calves $(P<0.05)$. No differences were seen in blood metabolites for glucose, serum urea $\mathrm{N}$, or BHB concentrations.

\section{Nitrogen Balance Period}

Results from the $\mathrm{N}$ balance phase are shown in Table 5. No differences were seen in $\mathrm{N}$ intake among treatments. Calves fed CON had greater fecal DM output compared with calves fed AGG $(P<0.05)$. Calves fed AGG had the greatest urine volume, and CON calves had the lowest $(P<0.05)$. Calves fed AGG and MOD had the greatest urine $\mathrm{N}$ output $(P<0.05)$, but no differences were noted among treatments for $\mathrm{N}$ fecal output. Calves fed CON had the greatest N efficiency, with AGG and MOD calves having similar but lower efficiencies $(P<0.05)$.

\section{Digestibility Measurement Period}

Data collected during the digestion measurement period are shown in Table 6 . Body weight of calves differed, with calves fed AGG being heaviest, MOD being intermediate, and calves fed CON being the lightest $(P$ $<0.05)$. Calves on AGG consumed the most MR and the least amount of starter $(P<0.05)$; however, there were no differences in DMI during the digestion phase. We detected a trend for DMI per kilogram of BW to be greatest in CON-fed calves compared with AGG- and MOD-fed calves. Calves fed AGG and MOD had greater nutrient digestibility percentages for DM, starch, fat, and $\mathrm{OM}$, and nutrient digestibility tended to be greater for $\mathrm{CP}, \mathrm{ADF}$, and NDF in AGG and MOD-fed calves 
Table 4. Postweaning week intake, growth, and blood measurements of calves fed 3 milk replacer (MR) $\operatorname{programs}^{1}$ (d 50 to 56$)$

\begin{tabular}{|c|c|c|c|c|c|}
\hline \multirow[b]{2}{*}{ Item } & \multicolumn{3}{|c|}{ Treatment (Trt) } & \multirow[b]{2}{*}{ SEM } & \multirow{2}{*}{$\frac{P \text {-value }}{\text { Trt }}$} \\
\hline & $\mathrm{CON}$ & MOD & AGG & & \\
\hline DMI (starter), g/d & 2,273 & 2,236 & 2,165 & 145 & 0.87 \\
\hline $\mathrm{MEI},{ }^{2} \mathrm{Mcal} / \mathrm{d}$ & 7.27 & 7.16 & 6.93 & 0.46 & 0.87 \\
\hline Water intake, $\mathrm{kg} / \mathrm{d}$ & 2.70 & 2.72 & 2.62 & 0.20 & 0.93 \\
\hline CP intake, $\mathrm{g} / \mathrm{d}$ & 478 & 468 & 454 & 30.1 & 0.85 \\
\hline Fat intake, $\mathrm{g} / \mathrm{d}$ & 71.1 & 70.1 & 67.7 & 4.50 & 0.86 \\
\hline Weight, $\mathrm{kg}$ & 75.2 & 78.8 & 82.0 & 2.25 & 0.14 \\
\hline $\mathrm{ADG}, \mathrm{g} / \mathrm{d}$ & 1,034 & 1,050 & 1,303 & 205 & 0.60 \\
\hline ADG/DMI & 0.44 & 0.46 & 0.60 & 0.09 & 0.40 \\
\hline ADG/MEI, g/Mcal & 139 & 142 & 188 & 27.2 & 0.39 \\
\hline $\mathrm{ADG} / \mathrm{CP}$ intake, $\mathrm{g} / \mathrm{g}$ & 2.11 & 2.18 & 2.87 & 0.42 & 0.39 \\
\hline DMI, $\mathrm{g} / \mathrm{kg}$ of BW & 30.1 & 28.2 & 26.4 & 1.27 & 0.16 \\
\hline $\mathrm{CP}$ intake, $\mathrm{g} / \mathrm{kg}$ of $\mathrm{BW}$ & 6.33 & 5.90 & 5.53 & 0.26 & 0.14 \\
\hline Fat intake, $\mathrm{g} / \mathrm{kg}$ of $\mathrm{BW}$ & 0.94 & 0.88 & 0.82 & 0.04 & 0.14 \\
\hline MEI, kcal/kg of BW & 96.3 & 90.1 & 84.4 & 4.01 & 0.16 \\
\hline Withers height, cm & 88.3 & 89.7 & 90.7 & 0.63 & 0.05 \\
\hline Withers height gain, $\mathrm{cm} / \mathrm{d}$ & 0.22 & 0.26 & 0.15 & 0.05 & 0.38 \\
\hline Hip height, cm & 91.5 & 92.5 & 94.3 & 0.77 & 0.07 \\
\hline Hip height gain, $\mathrm{cm} / \mathrm{d}$ & 0.25 & 0.18 & 0.20 & 0.07 & 0.77 \\
\hline Hip width, cm & $30.4^{\mathrm{b}}$ & $31.3^{\mathrm{a}}$ & $31.5^{\mathrm{a}}$ & 0.24 & 0.01 \\
\hline Hip width gain, $\mathrm{cm} / \mathrm{d}$ & 0.09 & 0.12 & 0.10 & 0.03 & 0.76 \\
\hline Heart girth, cm & 96.6 & 97.9 & 99.7 & 1.07 & 0.16 \\
\hline Heart girth gain, $\mathrm{cm} / \mathrm{d}$ & 0.23 & 0.22 & 0.41 & 0.06 & 0.06 \\
\hline Body length, cm & 75.8 & 77.6 & 78.3 & 1.31 & 0.41 \\
\hline Body length gain, $\mathrm{cm} / \mathrm{d}$ & 0.32 & 0.46 & 0.14 & 0.09 & 0.06 \\
\hline Urea, mg/dL & 21.9 & 21.8 & 21.1 & 2.10 & 0.96 \\
\hline Glucose, mg/dL & 88.2 & 93.7 & 91 & 4.38 & 0.69 \\
\hline $\mathrm{BHB}, \mathrm{mmol} / \mathrm{L}$ & 0.29 & 0.25 & 0.23 & 0.02 & 0.10 \\
\hline
\end{tabular}

${ }^{\mathrm{a}, \mathrm{b}}$ Means in the same row with different superscripts differ $(P<0.05)$.

${ }^{1}$ Treatment $\mathrm{CON}=446 \mathrm{~g}$ of a $20 \% \mathrm{CP}, 20 \%$ fat $\mathrm{MR} ; \mathrm{MOD}=669 \mathrm{~g}$ of a $26 \% \mathrm{CP}, 18 \%$ fat $\mathrm{MR} ; \mathrm{AGG}=892$ g of a $26 \% \mathrm{CP}, 18 \%$ fat MR.

${ }^{2}$ Estimation of ME intake.

compared with the CON-fed calves. The quantity of nutrients digested per unit of BW was similar among all treatments except that AGG-fed calves had greater fat digested per unit of BW compared with MOD and CON $(P<0.05)$.

\section{Overall Experiment}

Over the entire experiment, no differences were noted among treatments for DMI, MEI, water intake, or CP intake (Table 7). Calves fed AGG had the greatest fat

Table 5. Nitrogen metabolism from calves 35 to $42 \mathrm{~d}$ of age fed 3 milk replacer (MR) programs ${ }^{1}$ (d 50 to 56 )

\begin{tabular}{|c|c|c|c|c|c|}
\hline \multirow[b]{2}{*}{ Item } & \multicolumn{3}{|c|}{ Treatment (Trt) } & \multirow[b]{2}{*}{ SEM } & \multirow{2}{*}{$\frac{P \text {-value }}{\text { Trt }}$} \\
\hline & $\mathrm{CON}$ & MOD & AGG & & \\
\hline $\mathrm{N}$ intake, $\mathrm{g} / \mathrm{d}$ & 51.5 & 54.9 & 52.8 & 3.72 & 0.80 \\
\hline Urine output, $\mathrm{kg} / \mathrm{d}$ & $2.10^{\mathrm{c}}$ & $3.23^{\mathrm{b}}$ & $4.43^{\mathrm{a}}$ & 155 & $<0.001$ \\
\hline $\mathrm{N}$ urine output, $\mathrm{g} / \mathrm{d}$ & $12.1^{\mathrm{b}}$ & $17.0^{\mathrm{a}}$ & $18.2^{\mathrm{a}}$ & 1.26 & 0.02 \\
\hline $\mathrm{N}$ in urine, $\%$ & 0.55 & 0.52 & 0.40 & 0.06 & 0.21 \\
\hline Fecal DM output, g/d & $333^{\mathrm{a}}$ & $243^{\mathrm{ab}}$ & $214^{\mathrm{b}}$ & 29.3 & 0.03 \\
\hline $\mathrm{N}$ fecal output, $\mathrm{g} / \mathrm{d}$ & 13 & 10.7 & 11 & 1.28 & 0.41 \\
\hline $\mathrm{N}$ in feces, $\%$ & $3.93^{\mathrm{b}}$ & $4.73^{\mathrm{ab}}$ & $5.21^{\mathrm{a}}$ & 0.27 & 0.02 \\
\hline $\mathrm{N}$ retention, $\mathrm{g}$ & 27.3 & 22.5 & 24.3 & 1.56 & 0.13 \\
\hline $\mathrm{N}$ efficiency, ${ }^{2} \%$ & $52.7^{\mathrm{a}}$ & $46.7^{\mathrm{b}}$ & $44.4^{\mathrm{b}}$ & 1.19 & 0.01 \\
\hline
\end{tabular}


intake $(P<0.05)$. Calves fed $\mathrm{CON}$ had the lowest ADG and feed efficiency expressed as ADG/DMI $(P<0.05)$. Feed efficiency expressed as either ADG per unit of CP or unit of MEI did not differ among treatments. Intakes of $\mathrm{DM}, \mathrm{CP}$, and $\mathrm{ME}$ per kilogram of $\mathrm{BW}$ did not differ among treatments but intake of fat per kilogram of BW was greatest for AGG-fed calves $(P<0.05)$. Hip height gain and hip width gain were lowest for CON-fed calves, and withers height gain and heart girth gain were similar among treatments over the entire study. No differences were seen in blood metabolites for glucose or serum urea $\mathrm{N}$; however, calves on $\mathrm{CON}$ had greater BHB concentrations than MOD and AGG throughout the 56-d trial $(P<0.05)$.

\section{DISCUSSION}

Our results support research by Cowles et al. (2006), Guindon et al. (2015), and Chapman et al. (2016), that observed calves consuming up to 0.9 to $1.3 \mathrm{~kg}$ DM of MR daily during the preweaning period gained more weight, had greater skeletal growth, and were more efficient than calves fed approximately $0.5 \mathrm{~kg} \mathrm{DM}$ of $\mathrm{MR}$. As shown in Figure 1, we found a significant treatment by week interaction for starter intake that resulted in an overall treatment effect. Overall, calves on the accelerated feeding programs consumed less starter than conventionally fed calves, which was attributed to the greater difference in starter intake during wk 3, 4, 5, and 6 of the preweaning period. In this study, calves fed AGG and MOD consumed only about $50 \%$ of starter that the CON-fed calves consumed during the preweaning period. Starter intake of AGG- and MOD-fed calves increased substantially during the weaning week (wk 7) when MR was reduced and during the postweaning week (wk 8) when MR was removed. This could be due to a highly nutrient dense MR fed at a high volume fulfilling most of the nutrient requirements of the calf, leaving little desire to eat starter. This can be correlated with lesser rumen development, as was seen in significant treatment by week interactions for BHB concentrations during the 56-d trial (Figure 2). Studies have suggested that circulating BHB levels may be an indicator of rumen epithelial development and starter intake in preweaned calves (Quigley et al., 1991; Deelen et al., 2016). Quigley et al. (1991) observed that total blood concentrations of VFA were greater in calves weaned early and that blood VFA responded rapidly to dry feed intake. Khan et al. (2011) concluded that increasing $\mathrm{BHB}$ concentrations in the blood as calves aged was mainly due to a shift in the sources of physiological fuel during the transition from liquid to solid diets. Control-fed calves had greater BHB concentrations throughout this study because they were consuming a significantly greater amount of starter in the preweaning period compared with the calves fed the moderately

Table 6. Body weights, intakes, and apparent digestibilities of calves age 35 to $42 \mathrm{~d}$ of age fed 3 milk replacer (MR) $\operatorname{programs}^{1}$ (d 50 to 56 )

\begin{tabular}{lccccc}
\hline & \multicolumn{3}{c}{ Treatment (Trt) } & & P-value \\
\cline { 2 - 4 } Item & CON & MOD & AGG & SEM & Trt \\
\cline { 2 - 5 } BW, kg & $56.6^{\mathrm{c}}$ & $59.6^{\mathrm{b}}$ & $64.1^{\mathrm{a}}$ & 1.57 & 0.02 \\
MR intake, g/d & $446^{\mathrm{c}}$ & $666^{\mathrm{b}}$ & $878^{\mathrm{a}}$ & 7.46 & $<0.001$ \\
Starter intake, g/d & $1,123^{\mathrm{a}}$ & $729^{\mathrm{b}}$ & $437^{\mathrm{b}}$ & 101 & 0.001 \\
DMI, kg/d & 1.48 & 1.34 & 1.33 & 0.11 & 0.55 \\
DMI, g/kg of BW & 26.0 & 21.8 & 20.8 & 1.46 & 0.06 \\
Digestibility, \% & & & & & \\
DM & $78.9^{\mathrm{b}}$ & $83.6^{\mathrm{a}}$ & $84.0^{\mathrm{a}}$ & 0.85 & 0.002 \\
OM & $79.8^{\mathrm{b}}$ & $84.4^{\mathrm{a}}$ & $84.4^{\mathrm{a}}$ & 0.88 & 0.003 \\
CP & 75 & 79.3 & 79.1 & 1.32 & 0.06 \\
ADF & 48.9 & 57 & 62.4 & 3.99 & 0.09 \\
NDF & 58.2 & 68.7 & 68.7 & 3.17 & 0.05 \\
Starch & $96.6^{\mathrm{b}}$ & $99.2^{\mathrm{a}}$ & $99.5^{\mathrm{a}}$ & 0.50 & 0.002 \\
Fat & $93.9^{\mathrm{b}}$ & $95.1^{\mathrm{ab}}$ & $96.1^{\mathrm{a}}$ & 0.47 & 0.02 \\
Digested, g/kg of BW & & & & & \\
OM & 19.2 & 17.1 & 16.3 & 1.02 & 0.16 \\
CP & 4.09 & 4.18 & 4.09 & 0.23 & 0.95 \\
ADF & 0.98 & 0.96 & 1.00 & 0.06 & 0.87 \\
NDF & 2.40 & 2.36 & 2.36 & 0.16 & 0.98 \\
Starch & 9.70 & 8.35 & 8.00 & 0.53 & 0.09 \\
Fat & $2.08^{\mathrm{c}}$ & $2.31^{\mathrm{b}}$ & $2.65^{\mathrm{a}}$ & 0.04 & $<0.001$ \\
\hline
\end{tabular}

${ }^{\mathrm{a}-\mathrm{c}}$ Means in the same row with different superscripts differ $(P<0.05)$.

${ }^{1}$ Treatment $\mathrm{CON}=446 \mathrm{~g}$ of a $20 \% \mathrm{CP}, 20 \%$ fat $\mathrm{MR} ; \mathrm{MOD}=669 \mathrm{~g}$ of a $26 \% \mathrm{CP}, 18 \%$ fat $\mathrm{MR} ; \mathrm{AGG}=892$ $\mathrm{g}$ of a $26 \% \mathrm{CP}, 18 \%$ fat MR. 
Table 7. Overall performance of calves fed 3 milk replacer (MR) programs ${ }^{1}$ over the $56-\mathrm{d}$ trial

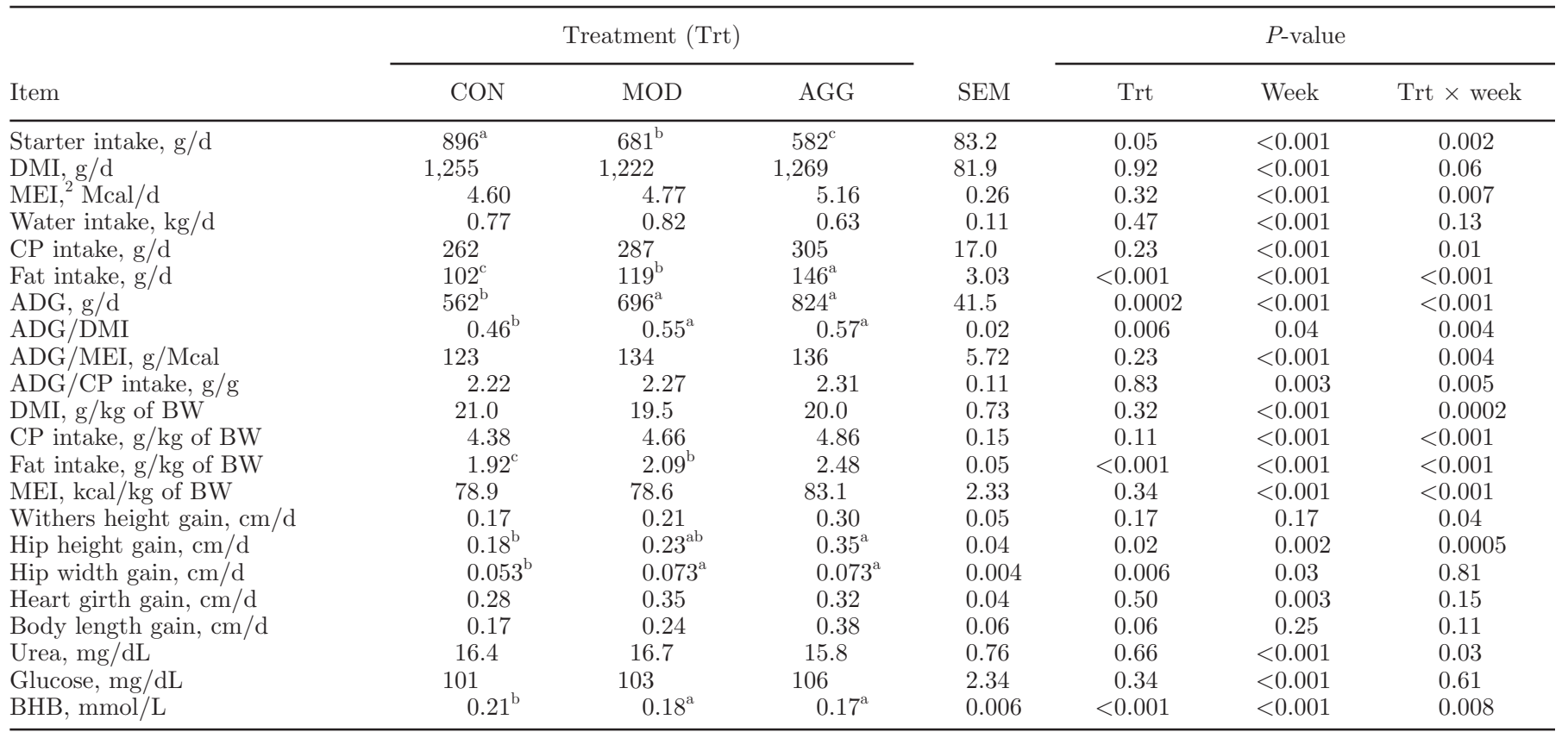

${ }^{\mathrm{a}-\mathrm{c}}$ Means in the same row with different superscripts differ $(P<0.05)$.

${ }^{1}$ Treatment $\mathrm{CON}=446 \mathrm{~g}$ of a $20 \% \mathrm{CP}, 20 \%$ fat MR; MOD $=669 \mathrm{~g}$ of a $26 \% \mathrm{CP}, 18 \%$ fat $\mathrm{MR}$; AGG $=892 \mathrm{~g}$ of a $26 \% \mathrm{CP}, 18 \%$ fat $\mathrm{MR}$.

${ }^{2}$ Estimation of ME intake.

high protein MR (Figures 1 and 2). Dry matter intakes were similar among treatments $(P=0.92)$; however, there was a trend for a treatment by week interaction $(P=0.06$; Figure 3$)$.

Water intake was not different among treatmentss $(P$ $=0.47$; Figure 4$)$. As shown in Figure 4 , when calves began weaning at wk 6 , more water was consumed among treatments during wk 7 and 8 compared with the preweaning week. This is in contrast to a study by Guindon et al. (2015), which found that calves fed up to $1.1 \mathrm{~kg}$ DM of MR daily consumed 1.6 times the amount of water compared with calves fed $0.44 \mathrm{~kg}$ DM of MR daily. Those authors attributed the difference to the nutrient density being greater in the high-protein MR (17\% solids) and likely causing an osmolality effect that, combined with greater tissue accretion, may have

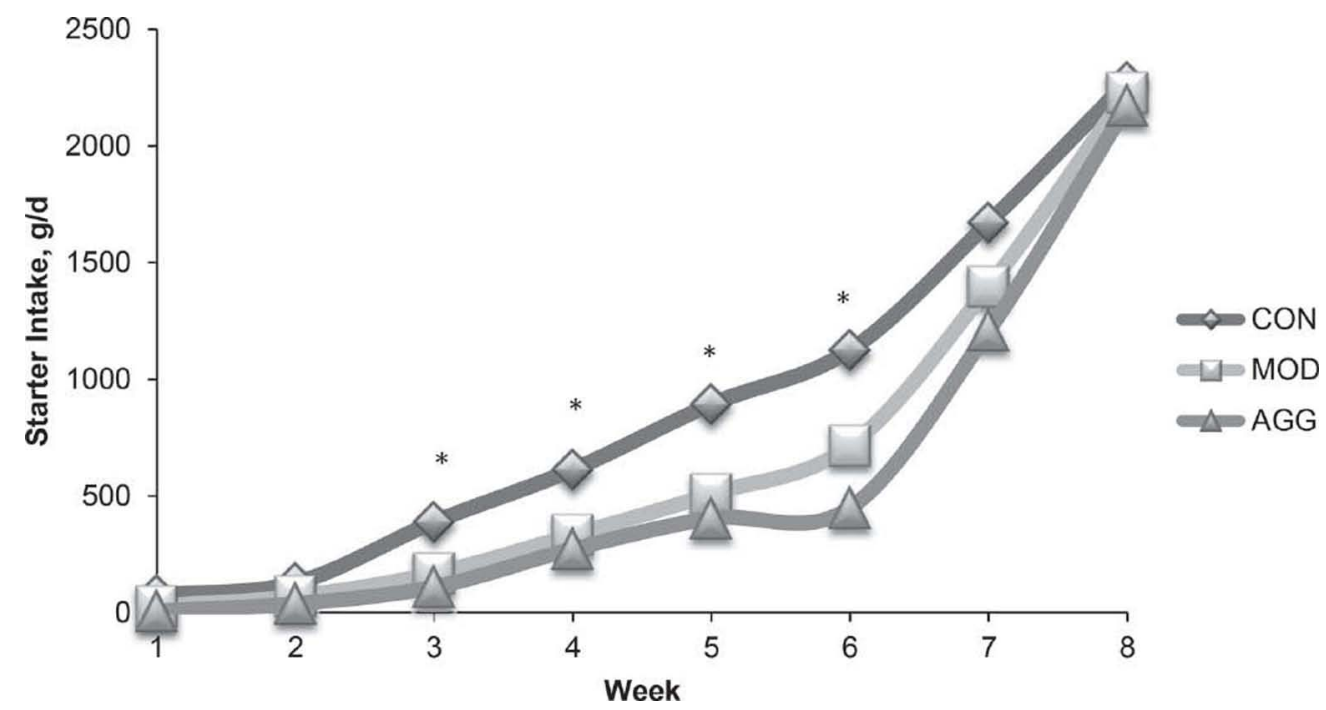

Figure 1. Weekly starter intake of calves fed 3 milk replacer (MR) programs throughout the 56 -d study. CON $=446 \mathrm{~g}$ of a $20 \% \mathrm{CP}, 20 \%$ fat MR; MOD $=669 \mathrm{~g}$ of a $26 \% \mathrm{CP}, 18 \%$ fat $\mathrm{MR} ; \mathrm{AGG}=892 \mathrm{~g}$ of a $26 \% \mathrm{CP}, 18 \%$ fat MR. SE $=83.2 .{ }^{*}$ Control differs $(P<0.05)$ from both MOD and AGG. 


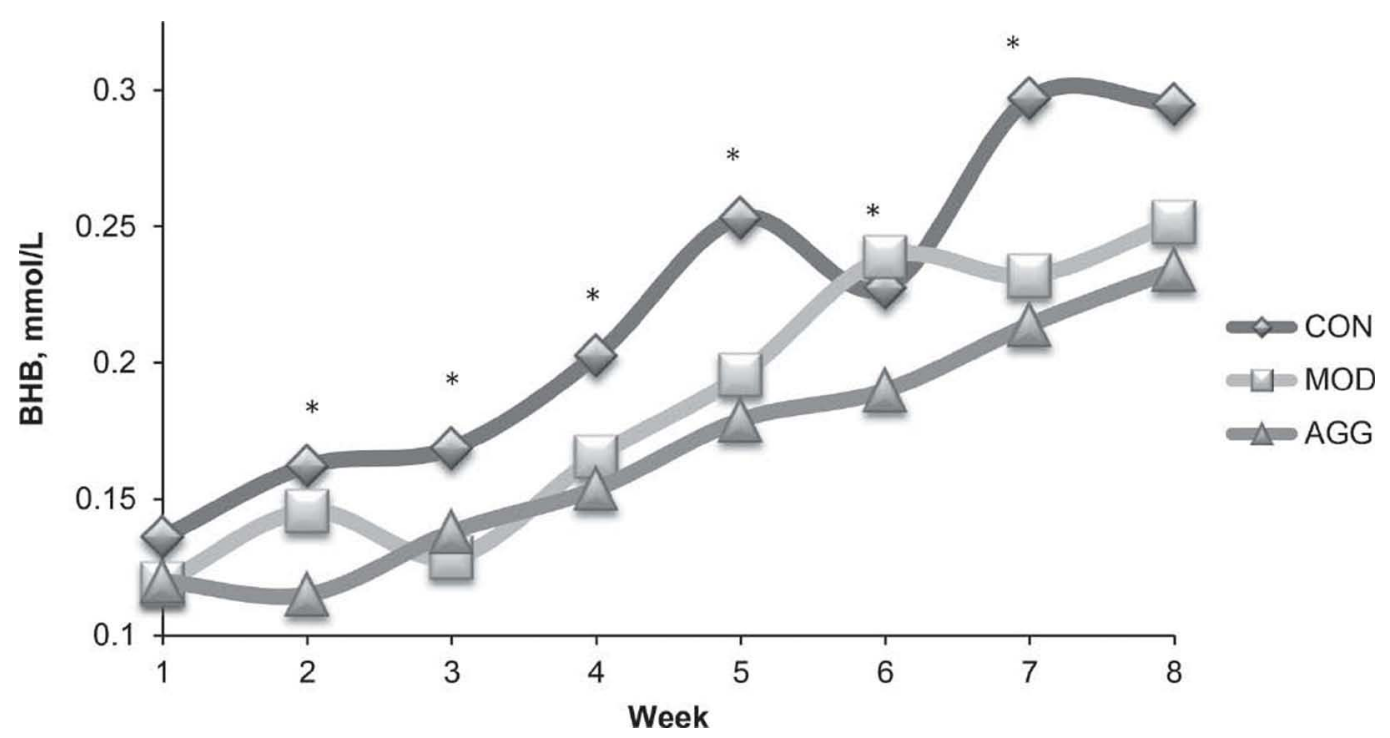

Figure 2. Weekly BHB concentrations of calves fed 3 milk replacer (MR) programs throughout the $56-\mathrm{d}$ study. CON $=446 \mathrm{~g}$ of a $20 \% \mathrm{CP}$, $20 \%$ fat MR; MOD $=669 \mathrm{~g}$ of a $26 \% \mathrm{CP}, 18 \%$ fat $\mathrm{MR} ; \mathrm{AGG}=892 \mathrm{~g}$ of a $26 \% \mathrm{CP}, 18 \%$ fat MR. SE $=0.006 .{ }^{*}$ Control differs $(P<0.05)$ from both MOD and AGG.

driven calves to drink more water. Calves on the current study consumed less MR and the MR was reconstituted to only $13 \%$ solids.

We detected significant treatment by week interactions $(P=0.0002)$ for overall $\mathrm{ADG}$, as seen in Figure 5. There was a slight decrease in ADG for the AGG-fed calves during wk 6 , which could be due to calves being measured only once a week, and 6 of the 8 calves on AGG were weighed 1 or $2 \mathrm{~d}$ after the afternoon feeding of MR had ceased. The calves were weaned based on age, whereas measurements were taken only on Mondays or Thursdays and not based on age. During the preweaning period, AGG- and MOD-fed calves had greater ADG but did not maintain this advantage during the weaning and postweaning weeks. Cowles et al. (2006) observed that calves fed up to approximately $1.3 \mathrm{~kg}$ DM of MR daily had ADG $<20 \%$ of calves fed $0.44 \mathrm{~kg} \mathrm{DM}$ of MR daily during the weaning week. The stress of weaning was less pronounced in the current study because of lower MR intakes and greater starter intakes of AGG- and MOD-fed calves compared with those in Cowles et al. (2006). Cowles et al. (2006) con-

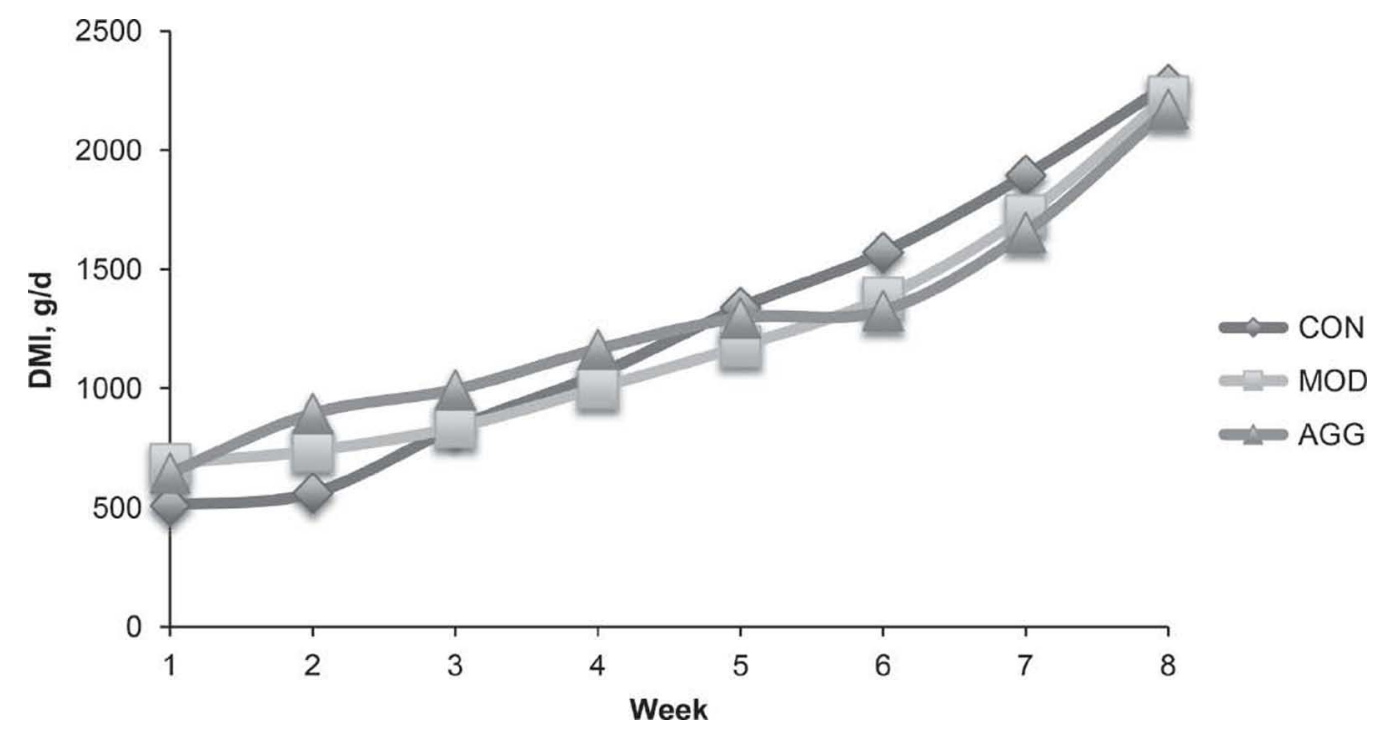

Figure 3. Weekly DMI of calves fed 3 milk replacer (MR) programs throughout the 56 -d study. CON $=446 \mathrm{~g}$ of a $20 \% \mathrm{CP}, 20 \%$ fat $\mathrm{MR}$; $\mathrm{MOD}=669 \mathrm{~g}$ of a $26 \% \mathrm{CP}, 18 \%$ fat $\mathrm{MR} ; \mathrm{AGG}=892 \mathrm{~g}$ of a $26 \% \mathrm{CP}, 18 \%$ fat $\mathrm{MR}$. SE $=81.9$. 
cluded that calves fed the intensified feeding regimen consumed less starter throughout the entire study, but had greater DMI, ADG, and gain-to-feed ratios during the preweaning period, but conventionally fed calves had greater gain-to-feed ratios during weaning. Their results showed that even though the conventionally fed heifers did not capitalize on early fast growth during the preweaning period, they were able to compensate in BW by d 63. Calves fed MOD and AGG on the current study did not maintain their weight advantage postweaning and this might be an example of compensatory growth occurring in the limit-MR-fed heifers (LaCasse et al., 1994). We found no differences in ADG or feed efficiency among treatments in the weaning and postweaning weeks, which could have been due to the lower intake of starter of calves fed MOD and AGG in the preweaning period that likely reduced the growth and feed efficiency of those calves later in the study. Calves fed MOD and AGG had a rapid increase of starter intake during the weaning week (wk 7) and postweaning week (wk 8), which could be associated with those calves accumulating more digesta and filling of the gut that calves fed CON already had; thus, their BW gain was artificially high.

Stamey et al. (2012) determined the effects of starter CP content on growth of Holstein calves from birth to 10 wk of age fed up to approximately $0.9 \mathrm{~kg} \mathrm{DM}$ of MR daily compared with approximately $0.5 \mathrm{~kg} \mathrm{DM}$ of MR daily. Those authors showed that calves fed the greater protein starter (25.5 vs. $19.6 \% \mathrm{CP}$ on a DM basis) had less slump in ADG and BW after weaning than calves fed the conventional starter with the high protein MR.
Calves in the current study were fed a starter with $20.7 \%$ CP on a DM basis, and a greater protein in this starter may have been beneficial to help increase starter intake for MOD- and AGG-fed calves. Also, having longer periods to gradually wean calves from larger intakes of MR can help overcome the stress of weaning and growth slump in calves fed large amounts of MR. Sweeney et al. (2010) evaluated starter intake using 4 weaning methods and found that calves on the $10-\mathrm{d}$ weaning program had the greatest advantage because they did not lose weight during the weaning phase and weighed as much as the calves weaned abruptly.

Figures 6 and 7 show significant treatment differences for overall withers and hip heights $(P<0.01)$. Calves fed AGG and MOD had greater withers and hip heights during the preweaning period, which agrees with previous studies (Cowles et al., 2006; Raeth-Knight et al., 2009; Stamey et al., 2012; Guindon et al., 2015).

Digestibility results were opposite those of other trials (Terré et al., 2007a,b; Hill et al., 2010, Chapman et al., 2016). However, those earlier experiments determined nutrient digestibilities after calves were weaned, whereas in the current study, calves were still being fed MR. Hill et al. (2010) observed reduced DM and OM digestibility in the immediate $3 \mathrm{~d}$ postweaning with calves fed up to $1.1 \mathrm{~kg} \mathrm{DM}$ of MR daily. In the current study, calves fed AGG and MOD had greater nutrient digestibility for percentage DM, starch, fat, and OM $(P<0.05)$ and tended to be greater for $\mathrm{CP}, \mathrm{ADF}$, and NDF $(P<0.10)$ compared with the CON-fed calves. This could be due to CON calves consuming $50 \%$ more starter, which is not as easy to digest. The quantities of

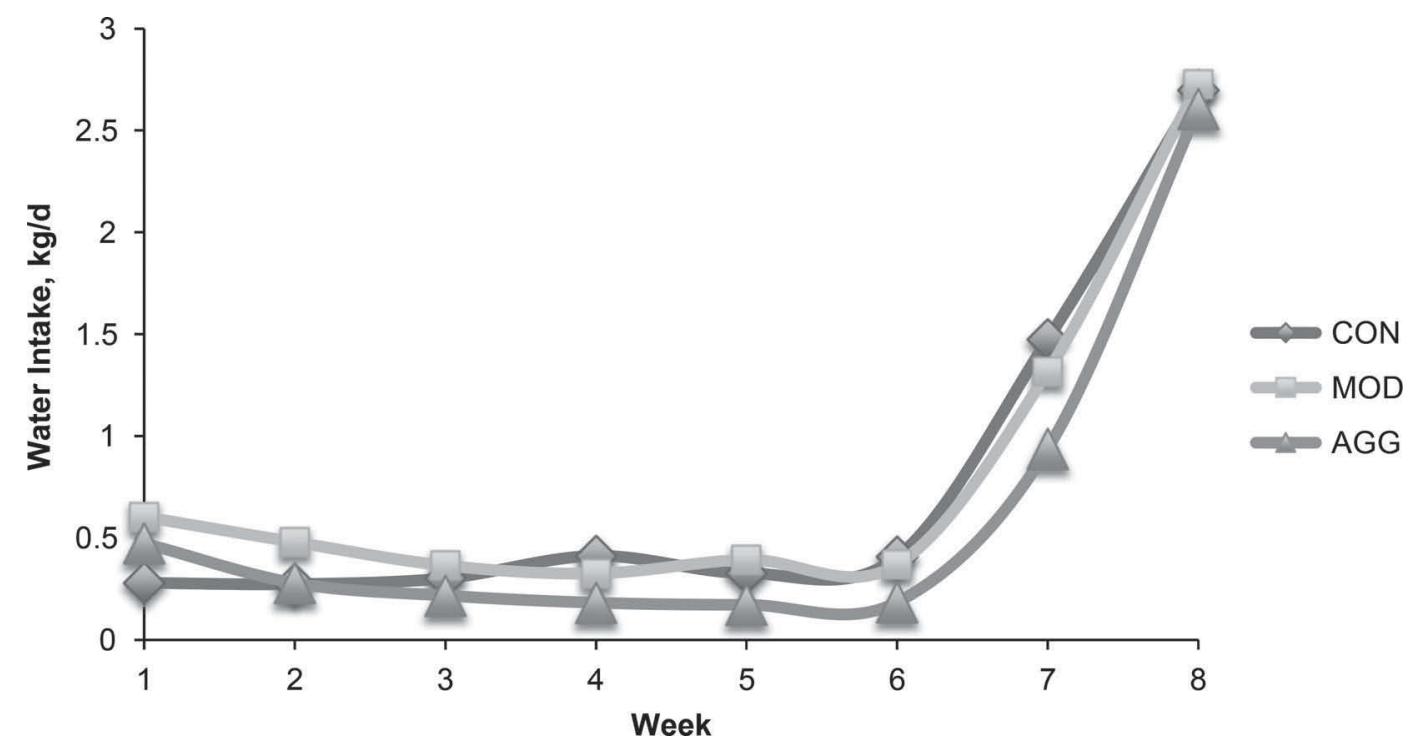

Figure 4. Weekly water intakes of calves fed 3 milk replacer (MR) programs throughout the 56 -d study. CON $=446 \mathrm{~g}$ of a $20 \% \mathrm{CP}, 20 \%$ fat $\mathrm{MR} ; \mathrm{MOD}=669 \mathrm{~g}$ of a $26 \% \mathrm{CP}, 18 \%$ fat $\mathrm{MR} ; \mathrm{AGG}=892 \mathrm{~g}$ of a $26 \% \mathrm{CP}, 18 \%$ fat MR. $\mathrm{SE}=0.11$. 


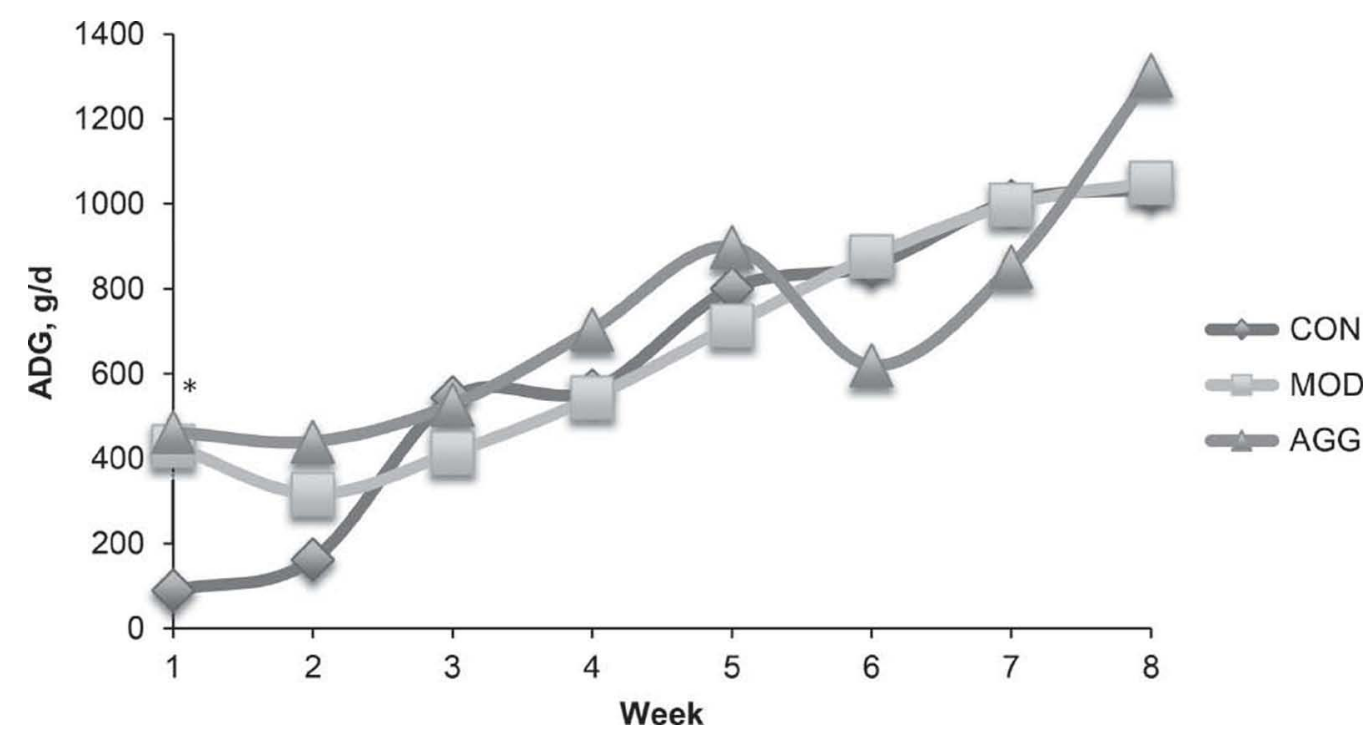

Figure 5. Weekly ADG of calves fed 3 milk replacer (MR) programs throughout the 56 -d study. CON $=446 \mathrm{~g}$ of a $20 \% \mathrm{CP}, 20 \%$ fat $\mathrm{MR}$; $\mathrm{MOD}=669 \mathrm{~g}$ of a $26 \% \mathrm{CP}, 18 \%$ fat $\mathrm{MR} ; \mathrm{AGG}=892 \mathrm{~g}$ of a $26 \% \mathrm{CP}, 18 \%$ fat MR. SE $=41.5 .{ }^{*}$ Control differs $(P<0.05)$ from both MOD and AGG.

nutrients digested per unit of BW were similar among all treatments except that AGG-fed calves had greater fat digested per unit of BW compared with MOD and CON. This was because the AGG calves had greater intake of fat per kilogram of BW during the preweaning period $(P<0.05)$. Hill et al. (2009) fed $0.66 \mathrm{~kg}$ $\mathrm{DM}$ of MR per calf daily that contained $14,17,20$, or $23 \%$ fat and determined preweaning nutrient digestibility through chromium oxide. Results showed that preweaning apparent digestibility of DM, OM, fat, and
NFC were linearly reduced as fat increased from 14 to $23 \%$, which agrees with the current study. Calves fed AGG and MOD had MR containing 18\% fat compared with $20 \%$ fat in the CON fed calves.

Excessive feeding of CP to lactating cows and growing replacement heifers has been shown to increase fecal and urinary $\mathrm{N}$, which can cause environmental problems (Wilkerson et al., 1997). Results from the N utilization phase showed that AGG and MOD treatments had similar but lower $\mathrm{N}$ efficiency than CON

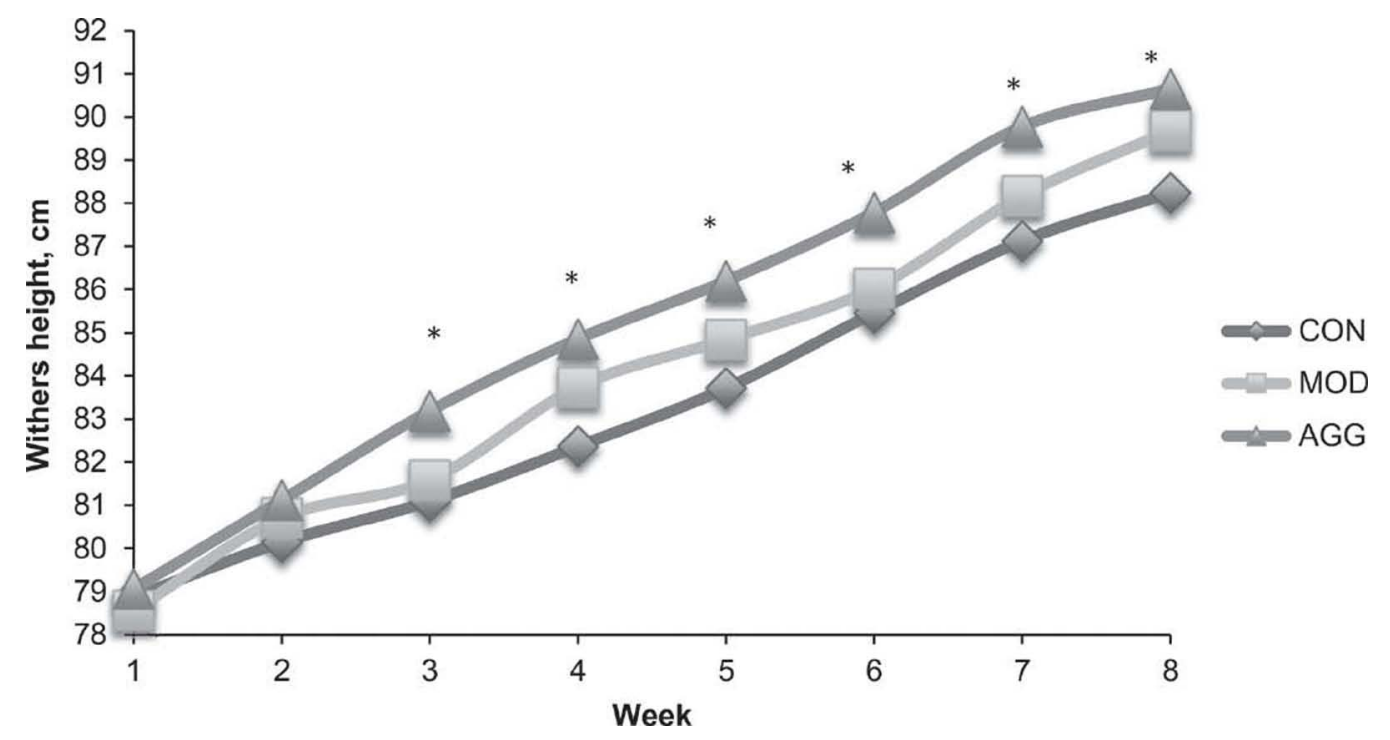

Figure 6. Weekly withers heights of calves fed 3 milk replacer (MR) programs throughout the 56 -d study. CON $=446 \mathrm{~g}$ of a $20 \% \mathrm{CP}, 20 \%$ fat MR; MOD $=669 \mathrm{~g}$ of a $26 \% \mathrm{CP}, 18 \%$ fat MR; $\mathrm{AGG}=892 \mathrm{~g}$ of a $26 \% \mathrm{CP}, 18 \%$ fat MR. SE $=0.47$. ${ }^{*}$ Control differs $(P<0.05)$ from both MOD and AGG. 


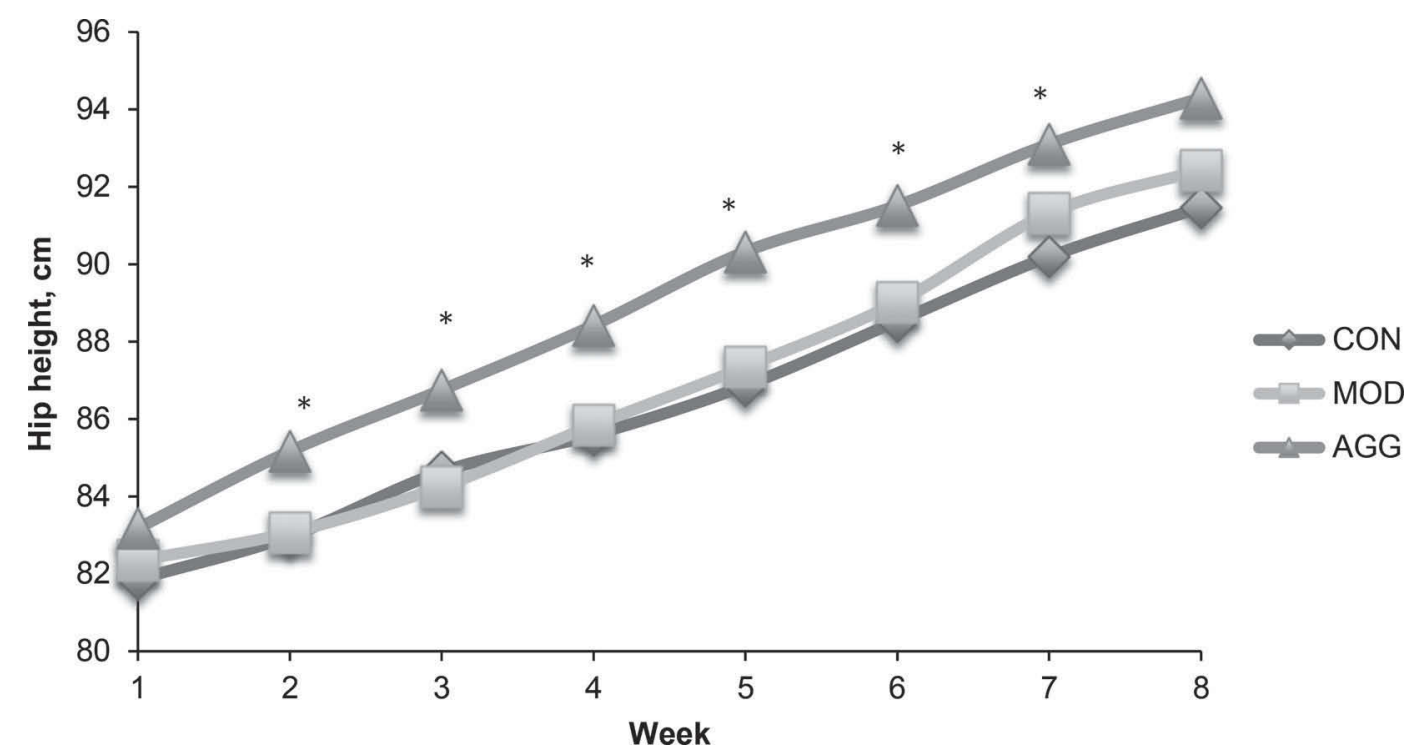

Figure 7. Weekly hip heights of calves fed 3 milk replacer (MR) programs throughout the 56-d study. CON $=446 \mathrm{~g}$ of a $20 \% \mathrm{CP}, 20 \%$ fat $\mathrm{MR} ; \mathrm{MOD}=669 \mathrm{~g}$ of a $26 \% \mathrm{CP}, 18 \%$ fat $\mathrm{MR} ; \mathrm{AGG}=892 \mathrm{~g}$ of a $26 \% \mathrm{CP}, 18 \%$ fat MR. $\mathrm{SE}=0.81 .{ }^{*}$ Control differs $(P<0.05)$ from both MOD and AGG.

calves. This could be due to AGG and MOD calves having greater urine volume and thereby, greater combined urine $\mathrm{N}$ output compared with CON. Calves fed AGG and MOD did not utilize dietary $\mathrm{N}$ as efficiently as calves fed CON. Blome et al. (2003) determined N balance measurements during wk 3 and 4 of the experimental period and showed that retained $\mathrm{N}$ increased linearly $(P<0.001)$ as dietary $\mathrm{CP}$ increased. In that study, treatments were isocaloric MR ( $12.5 \%$ solids) fed at $12 \%$ of BW that contained 16.1, 18.5, 22.9, or $25.8 \% \mathrm{CP}$ and no starter was offered. Calves in the current study had similar $\mathrm{N}$ retention values but $\mathrm{AGG}$ and MOD had lower N efficiency values. Estimates of N excretion from preweaned calves fed these high feeding rates of milk and MR are vital to evaluate the economic and environmental impacts of aggressive feeding programs (Wilkerson et al., 1997).

No effects of treatment were seen on serum urea $\mathrm{N}$ or glucose concentrations $(P=0.66$ and $P=0.34$, respectively). Blood glucose levels decreased throughout the 8 wk of the study regardless of treatment, which can be attributed to a physiological shift in the primary energy source from glucose to VFA when the rumen in young calves becomes functional (Hammon et al., 2002). Blome et al. (2003) found that highest levels of plasma urea $\mathrm{N}$ were measured in calves fed the highest $\mathrm{CP}$ level, indicating that the calves on the $25.8 \% \mathrm{CP}$ level did not utilize protein as efficiently as the calves on the other 3 treatments. The serum urea $\mathrm{N}$ concentrations in the current study increased over the duration of the study in all heifers; however, no differences were noted among treatments. It is possible that $\mathrm{CON}-$ fed calves had more endogenous protein breakdown than AGG- or MOD-fed calves and they were also consuming more starter, indicating greater digestion of starter by the rumen microbiota, resulting in an increase in ammonia concentrations in the rumen.

The 3 MR feeding programs used in this study are currently being used for calves in the United States. Other studies have reported feeding calves $>26 \% \mathrm{CP}$ and $>900 \mathrm{~g}$ of DM daily from MR preweaning (Cowles et al., 2006; Hill et al., 2010; Guindon et al., 2015). However, these studies did not calculate $\mathrm{N}$ efficiency, but we may conclude a lower $\mathrm{N}$ efficiency with greater $\mathrm{CP}$ and MR volumes based on the results of the current study.

\section{CONCLUSIONS}

Calves fed MOD and AGG had greater BW gain, structural growth, and feed efficiencies in the first 42-d preweaning period, but had reduced starter intakes and lowered $\mathrm{N}$ efficiency compared with calves fed CON. The over-feeding of CP in MOD- and AGG-fed calves increased urinary $\mathrm{N}$ output, which can have economic and environmental impacts. Over the 56-d study, BW and hip height gain were greater for calves fed MOD and AGG compared with CON. Serum BHB concentrations were greater in CON compared with MOD and AGG calves throughout the study. Dairy producers could use serum BHB concentrations as an easy indicator of rumen development in their calves. Data from our study indicate that calves fed amounts of MR over 
approximately $669 \mathrm{~g}$ of DM of a higher-protein milk replacer will result in lower $\mathrm{N}$ efficiency and reduced rumen development.

\section{ACKNOWLEDGMENTS}

The authors thank Provimi North America (Brookville, OH) and the New Hampshire Agricultural Experiment Station (Durham). This is Scientific Contribution Number 2683. This work was supported by the USDA National Institute of Food and Agriculture (Washington, DC; NC-2042; accession number 1001283) and Provimi North America. The authors thank Provimi North America for the donation of the milk replacer, starter and financial support. The authors also thank the Fairchild Teaching and Research Center (University of New Hampshire) staff for use of the animals and assistance throughout the study.

\section{REFERENCES}

AOAC International. 1995. Official Methods of Analysis. 15th ed. AOAC International, Gaithersburg, MD.

AOAC International. 1999. Official Methods of Analysis. 16th ed. AOAC International, Gaithersburg, MD.

Appleby, M. C., D. M. Weary, and B. Chua. 2001. Performance and feeding behaviour of calves on ad libitum milk from artificial teats. Appl. Anim. Behav. Sci. 74:191-201.

Bartlett, K. S., F. K. McKeith, M. J. VanderHaar, G. E. Dahl, and J. K. Drackley. 2006. Growth and body composition of dairy calves fed milk replacers containing different amounts of protein at two feeding rates. J. Anim. Sci. 84:1454-1467.

Blome, R. M., J. K. Drackley, F. K. Keith, M. F. Hutjens, and G. C. McCoy. 2003. Growth, nutrient utilization, and body composition of dairy calves fed milk replacers fed different amounts of protein. J. Anim. Sci. 81:1641-1655.

Chapman, C. E., P. S. Erickson, J. D. Quigley, T. M. Hill, H. G. Bateman II, F. X. Suarez-Mena, and R. L. Scholetterbeck. 2016 Effect of milk replacer program on calf performance and digestion of nutrients with age of the dairy calf. J. Dairy Sci. 99:2740-2747.

Cowles, K. E., R. A. White, N. L. Whitehouse, and P. S. Erickson. 2006. Growth characteristics of calves fed an intensified milk replacer regimen with additional lactoferrin. J. Dairy Sci. 89:48354845.

Davis, C. L., and J. K. Drackley. 1998. The Development, Nutrition, and Management of the Young Calf. Iowa State University Press, Ames.

Deelen, S. M., K. E. Leslie, M. A. Steele, E. Eckert, H. E. Brown, and T. J. DeVries. 2016. Validation of a calf-side $\beta$-hydroxybutyrate test and its utility for estimation of starter intake in dairy calves around weaning. J. Dairy Sci. 99:7624-7633.

Diaz, M. C., M. E. Van Amburgh, J. M. Smith, J. M. Kelsey, and E. L. Hutten. 2001. Composition of growth of Holstein calves fed milk replacer from birth to 105-kilogram body weight. J. Dairy Sci. 84:830-842.

Guindon, N. E., N. T. Antaya, R. G. Cabral, N. L. Whitehouse, T. J. Earleywine, and P. S. Erickson. 2015. Effects of human visita- tion on calf growth and performance of calves fed different milk replacer feeding levels. J. Dairy Sci. 98:8952-8961.

Hammon, H. M., G. Schiessler, A. Nussbaum, and J. W. Blum. 2002. Feed intake patterns, growth performance, and metabolic and endocrine traits in calves fed unlimited amounts of colostrum and milk by automate, starting in the neonatal period. J. Dairy Sci. $85: 3352-3362$

Hill, T. M., H. G. Bateman II, J. M. Aldrich, and R. L. Schlotterbeck. 2009. Effects of fat concentration of a high-protein milk replacer on calf performance. J. Dairy Sci. 92:5147-5153.

Hill, T. M., H. G. Bateman II, J. M. Aldrich, and R. L. Schlotterbeck. 2010. Effects of milk replacer on digestion of nutrients in dairy calves. J. Dairy Sci. 93:1105-1115.

Huber, J. T., A. G. Silva, O. F. Campos, and C. M. Mathieu. 1984 Influence of feeding different amounts of milk on performance, health, and absorption capability of baby calves. J. Dairy Sci. 67:2957-2963.

Jasper, J., and D. M. Weary. 2002. Effects of ad libitum milk intake on dairy calves. J. Dairy Sci. 85:3054-3058.

Kertz, A. F. and J. R. Loften. 2013. Review: A historical perspective of specific milk-replacer feeding programs in the United States and effects on eventual performance of Holstein dairy calves. Prof. Anim. Sci. 29:321-332

Kertz, A. F., L. R. Prewitt, and J. P. Everett Jr.. 1979. An early weaning calf program: Summarization and review. J. Dairy Sci 62:1835-1843.

Khan, M. A., D. M. Weary, and M. A. G. von Keyerslingk. 2011. Invited review: Effects of milk ration on solid feed intake, weaning, and performance in dairy heifers. J. Dairy Sci. 94:1071-1081.

Lacasse, P., E. Block, and D. Peticlerc. 1994. Effect of plane of nutrition before and during gestation on the concentration of hormones in dairy heifers. J. Dairy Sci. 77:439-445.

NRC. 2001. Nutrient Requirements of Dairy Cattle. 7th rev. ed. Natl. Acad. Sci., Washington, D.C.

Otterby, D. E., and J. G. Linn. 1981. Advances in nutrition and management of calves and heifers. J. Dairy Sci. 64:1365-1377.

Quigley, J. D. III, Z. P. Smith, and R. N. Heitmann. 1991. Changes in plasma volatile fatty acids in response to weaning and feed intake in young calves. J. Dairy Sci. 74:258-263.

Raeth-Knight, M. L., H. Chester-Jones, S. Hayes, J. Linn, R. Larson, D. Ziegler, B. Ziegler, and N. Broadwater. 2009. Impact of conventional or intensive milk replacer programs on Holstein heifer performance through six months of age and during first lactation. J. Dairy Sci. 92:799-809.

Stamey, J. A., N. A. Janovick, A. F. Kertz, and J. K. Drackley. 2012 Influence of starter protein content on growth of dairy calves in an enhanced early nutrition program. J. Dairy Sci. 95:3327-3336.

Sweeney, B. C., J. Rushen, D. M. Weary, and A. M. dePassille. 2010 Duration of weaning, starter intake, and weight gain of dairy calves fed large amounts of milk. J. Dairy Sci. 93:148-152.

Terré, M., M. Devant, and A. Bach. 2007a. Effect of level of milk replacer fed to Holstein calves on performance during the preweaning period and starter digestibility at weaning. Livest. Sci. 110:82-88.

Terré, M., M. Devant, and A. Bach. 2007b. Performance and nitrogen metabolism of calves fed conventionally or following an enhancedgrowth feeding program during the preweaning period. Livest. Sci. 105:109-119.

Tikofsky, J. N., M. E. Van Amburgh, and D. A. Ross. 2001. Effect of varying carbohydrate and fat content of milk replacer on body composition of Holstein bull calves. J. Anim. Sci. 79:2260-2267.

Wilkerson, V. A., D. R. Mertens, and D. P. Casper. 1997. Prediction of excretion of manure and nitrogen by Holstein dairy cattle. J. Dairy Sci. 80:3193-3204. 